\title{
The Use of Cooperative Learning With Number Head Together Model to Improve the Students' Mathematics Subject
}

\author{
Nasrun \\ Mathematics Department, Muhammadiyah University of Makassar
}

\begin{abstract}
This research was a class action that begins with the development of learning tools. The subjects were students of class V SD Inpres Mallengkeri Makassar in the academic year 2015/2016, the number of students 45, there were 22 male students and 23 female students. The research was conducted in two (2) cycles. Each cycle consists of four phases: planning (planning), action (action), observations (observation) and reflection (reflection). The results of this research were to increase student learning thoroughness of the first cycle to the second cycle. If the first cycle the number of pupils who achieve complete category amounted to 28 people or 68.3 per cent, then the second cycle of the entire student has managed to achieve complete category. It can be concluded that the application of learning models Number Head Together has a role in improving student learning outcomes
\end{abstract}

Keywords: Type Cooperative Learning Outcomes and Numbered Head Together

\section{Introduction}

One thing that plays an important role for the success of the implementation process of teaching is teaching. Implementation of good teaching is strongly influenced by good planning anyway. Teaching was a core of interaction between teachers and students in the learning process. The process of learning and teaching are two different things but form a single unit, like a two-sided coin. Learning is an activity undertaken by students, teaching is an activity performed by guru. Teaching activity undertaken by teachers affect student learning activities. In order for the implementation of the teaching run efficiently and effectively will require planning systematically arranged with the learning process more meaningful and enable the students.

In the process of learning, the process is interaction between teachers and students who interact. Not only teachers affect students, but students can also affect teachers. The interaction in the learning process not only occurs among students, but among students in human resources (that is, those who can give information), and between students with learning media. Similarly, in the process of teaching mathematics interaction between students and teachers should happen dialog. It is intended that the teacher can give students the motivation to generate interest for conducting study mathematics. As previously disclosed in the learning process interactions occur not only among students, but also between students and students. Teaching system provides opportunities among students to work together in completing structured tasks referred to as the "cooperative learning" or "cooperative learning." In this case, the teacher acts as a facilitator.

Given the importance of mathematics for elementary students education since it is necessary to look for a solution that is a way to manage the process of teaching and learning mathematics in elementary school, so that mathematics can be understood by students. In the effort to manage the process of learning mathematics in elementary school requires a particular strategy one of which is a cooperative learning. Some experts claim that this model is very useful to foster cooperation skills, critical thinking, and willingness to help friends and so on.

Cooperative learning is done have succeeded in improving student learning outcomes because it may allow students to learn from a friend (Slavin in Muslim Ibrahim, 2001: 39). Slavin also found cooperative learning to help each other create the conditions for success with not observed in any other learning. also looked at the results of research in developed countries found that cooperative learning can improve academic achievement both junior high and high school students.

Given the growing importance of interaction in the learning process, the implementation of cooperative learning strategies in education is important also to be implemented are included in the learning process. Although it is recognized that students get the most benefit from discussions that enable them, not many teachers who doing it. The strategy most often used to enable the student is to engage students in a discussion with all students in the class (Muhsin.A.M, 2012). This strategy is not very effective, though the teacher had tried and encourage students to participate, most students become spectators while classes controlled by a handful of people.

The classroom atmosphere needs to be planned and built so that students get a chance to interact with each other. In this interaction the students will form a community that allows them to love learning, and appreciate one another. In a learning atmosphere that is full of competition, student isolation, negative attitudes and relationships will be formed and stultify student. The atmosphere will inhibit the formation of active student 
learning. Therefore, teachers need to create an atmosphere of learning such that students work together in mutual cooperation.

Based on the information above, researchers focused to find out whether the type of cooperative learning implementing Numbered Head Together model, it can improve student learning outcomes in class V SD Negeri Inpres MallengkeriMakassar.

\section{Research Methods}

This research is a Classroom Action Research. The Classroom Action Research are conducted through the assessment process cycle. Each cycle or cycle consists of four phases: planning (planning), action (action), observations (observation) and reflection (reflection). The research was conducted on students of class V SD Negeri Inpres MallengkeriMakassar in the first semester of the academic year 2014/2015. The subjects were students of class V SD with the number of students 45 are 22 male students and 23 female students. The object of research is the result of learning and change attitudes of students in learning mathematics.

The main instrument in this study is the observation sheet contains components which will be observed on the activities of students during the learning process, learning outcomes test contains questions regarding the material on subjects integer arithmetic operations. This test is used to measure the achievement of students 'concept, and questionnaire responses students including questions to explore students' response to the implementation of learning using Cooperative Learning type Numbered Head Together.

\section{Results And Discussion}

Based on research exposure each cycle can be expressed as follows:

Cycle 1

\section{Planning}

Before doing research too much the first thing done by teachers is how to plan the learning process by applying the learning model of Number Heads Together (NHT). In this case how research undertakes a review of the curriculum, especially the primary school curriculum. This is done to achieve competency standards to be achieved in the subjects of Mathematics is to make learning scenarios by applying the learning model of Number Heads Together (NHT), create a lesson plan, create a worksheet students, making the observation sheet to see how the atmosphere of learning in the classroom, prepare a medium of learning in order to help students. To determine the capacity of students to apply the model of Number Heads Together (NHT) teacher made worksheet as tables' observation of experiments have been conducted. As for knowing everything that occurs during learning activities take place by applying the model Number Heads Together (NHT) researchers made the observation sheets for the students and teachers, as a means of collecting data.

\section{Implementation}

The implementation of the action on the first cycle lasts for one meetings with the length of time each meeting is $2 \times 35$ minutes. Meeting for the provision of initial proficiency test to determine students' understanding of the material will be given at the same time investigate whether pre-existing knowledge of the material to be taught has been owned by the students. At the beginning of the meeting before giving the material the teacher first submitting the prerequisite knowledge of the material to be taught that there is a picture on the pupil of the subject matter to be studied, after delivering a preliminary picture of the material to be taught, the teacher tells the purpose of learning so as to motivate students to learn to learn, After delivering the purpose of studying the learning materials start to the teacher presents the subject matter / information by applying the model Number Heads Together (NHT), after which the teacher then divides the students into small groups whose members numbered between 3-5 people.

Implementation of learning by applying the learning model of Number Heads Together (NHT) is applied to the learning objectives can be achieved in accordance with a predetermined RPP. In improving student learning motivation of teachers to reward (reinforcement) to a student who is able to accomplish the task given group, the students are on questions relating to the subject matter, students answered questions from teacher0. The award given by the teacher in the form of teaching thumb, the additional value etc. Pupils then worked Worksheet Pupil (MFI). During the application of learning models Number Heads Together (NHT) students must fully understand the story and drama texts did by child as the material of choice in this study, so that students can master the material thoroughly. Before starting the lesson, the teacher beforehand:

1) Establish learning objectives.

2) Provide guidance and establish measures the application of learning models Number Heads Together (NHT)

3) Prepare the tools needed for learning.

4) The teacher divides the MFI or other study materials.

5) The teacher gives emphasis to the students that they should not be an end to the learning activities until they are sure that the students do not understand the purpose of learning. 
6) Make sure students understand that the MFI had to learn, not to be charged and collected.

7) If a student has a question, the teacher asked them to put the question to a friend in their group, before submitting to the other students or teachers.

After a walk cycle with the application of learning models Number Heads Together (NHT) in the classroom, the teacher can reset a new group. The purpose of resetting the new group is to provide opportunities for students to work with another classmate and keep learning program is still running. This is achieved by the teacher because he wanted to see, whether there is an increase learning achievement of pupils in the second stage than its predecessors.

\section{Observation}

At this stage of the process carried out observations on the implementation of the action by using the application of learning models Number Heads Together (NHT) observation sheets that have been made and carry out an evaluation form achievement test cycle I. At this stage, researchers observed with attention to everything that happened in early learning activities until the end of the study, researchers monitored the learning activities that teachers using the experimental method. Researchers pay attention to the activities of teachers when learning takes place with reference to the format of research that has been prepared beforehand. In addition, the researchers also noticed activity of students during the learning takes place based on the format of the research that has been prepared.

Based on observations obtained a description that student interest and motivation for participating in learning activities the application of learning models Number Heads Together (NHT) is quite good. It can be seen from the description of learning completeness percentage of students in class V SD Negeri Inpres MallengkeriMakassar in the first cycle, which amounted to $68.3 \%$ or 28 of the 45 children included in the category of complete and $31.7 \%$ or 17 of the 45 children included in the category of not complete, meaning there were 13 students who need to be given remedial because they do not achieve mastery individual. This shows yet achieved a 70\% classical completeness The data are presented in the chart below.

The graph above gives illustrated that from 41 the number of students in class V. SD Negeri Inpres MallengkeriMakassar in the learning process the first cycle there are 17 students who do not achieve mastery individual. Students would not achieve mastery of this individual who then need special attention from the teacher. This meant that the attention in the implementation process of the next teaching can be increased, and achieve mastery individual. Factors affecting the 13 students did not achieve mastery caused by:

1) Students are less active in the learning process

2) Students do not focus or concentrate on the subject matter being discussed, both within the group or by the teacher

3) In the case of the task, the students have not been able to do well.

Of the factors mentioned above so that the teacher concluded that all 13 students have not achieved the standard value of completeness that need to perform remedial action and need special attention to the implementation of the second cycle.

\section{Reflection}

After going through the stages of implementation and at the same stage of observation and ends with the evaluation of student learning outcomes is done then the next stage of reflection, based on the observation and evaluation of obtained information that there are students who do other activities during learning activities take place. This may occur because of previous students have been accustomed to passively accept the teaching materials. It is necessary to continue in the second cycle by taking into account the above aspects.

\section{cycle II}

\section{Planning}

At this research stage was redesigning the lesson plan as a continuation of material from the first cycle by taking into account the recommendations of the first cycle, planning activities continued with create research instruments such as achievement test and observation sheet.

Creating a lesson plan, create a worksheet pupil, which is the teachers' assessment in terms of understanding the story and text drama child saying, made the observation sheet as a means of collecting data to determine how the conditions of teaching and learning in the classroom during the course of the learning activities, both students and teachers, making an evaluation tool, form study groups based on the results of the initial test evaluation.

\section{Implementation}

The implementation of the measures in this second cycle lasts for one meetings with the length of time each meeting is $2 \times 35$ minutes. The learning process continued with the interaction of the other pupils, and the continuation of a summary and synthesis as presented in the RPP. 
In the early-face teachers deliver material in accordance with the lesson plan. After teacher explains the subject matter, the students were asked to ask things that do not understand in relation to the previous material. The teacher then distributes Worksheet pupil (MFIs) to work in groups to interact to disciple others, in addition to students working on MFI researchers monitored during learning activities take place under the guidance of observation. Teachers then provide questions to the students by calling out the same number of students for each group, and each group of answers was later the teacher asked students to give each opinion on the material already in the group, which is about the story and drama texts saying child.

Implementation of the proficiency tests given to students through the application of learning models Number Heads Together (NHT). Furthermore, each group summarize and present it to the class by the teacher's instructions. The trick is called the serial number of teachers who have been determined prior to the learning process. Thus, each student has the same number should be next read out and submit a summary of which has been discussed in each group.

\section{Observation}

At this stage of the process did observations on the implementation of the action using observation sheet that has been made and carry out an evaluation form achievement test first cycle after the meeting. Achievement test comes in the form description as contained in the attachment.

Based on observations obtained a description that student interest and motivation for following the activities of teaching good enough. Good enough student interest and motivation to learn implicated in increasing student learning achievement when compared with the results of learning in cycle I. Based on the results of the evaluation in the form of student achievement test obtained with the application of learning instructional improvement model of Number Heads Together (NHT). This means that student learning outcomes on the second cycle of the application of learning with application of learning models Number Heads Together (NHT) is high. For more details can be seen in the chart below.

Overview percentage of mastery learning classr V SD Negeri Inpres MallengkeriMakassar on the second cycle from the graph above, it can be seen that there is a $100 \%$ or 45 of the 45 children included in the category completely. It shows all the students have achieved a $70 \%$ classical completeness So that should not be continued in the next cycle.

Based on the graph above, it is known that an increase mastery learning students from the first cycle to the second cycle. If the first cycle the number of pupils who achieve complete category amounted to 28 people or 68.3 per cent, then the second cycle of the entire student has managed to achieve complete category. This means that in the first cycle there are 17 people or 31.7 percent of which must follow remedial, while in the second cycle there are students who have to follow remedial because all students have achieved mastery learning. Thus it can be noted that the application of learning models Number Head Together has a role in improving student learning achievement.

\section{Reflection}

After going through the stages of implementation and at the same stage of observation and ends with the evaluation of student learning outcomes is done then the next stage of reflection, based on the observation and evaluation of obtained information that all students have achieved mastery. This means it can be said that the learning achievement of pupils can be improved with the application of cooperative learning with the type of Number Heads Together (NHT).

\section{Conclusion}

During this study took place in two cycles of the changes that occurred over the pupil can be argued that through the application of learning models Number Heads Together (NHT) can improve learning outcomes the students class V SD Negeri Inpres MallengkeriMakassar. Based on the results of the study, it showed that the learning achievement of pupils has increased.

\section{Suggestion}

1. In order for learning strategy and the application of learning models Number Heads Together (NHT) arranged such that it becomes more effective learning model to the points given subject.

2. The attempt will be made as early as possible to overcome the difficulties experienced by both pupils and teachers in the learning process. It can be based on the reflection in the form of changes that occur when the learning process or drawn from the responses that the student himself.

3. In order for the authorities pay more attention to the quality of education with more to give moral support and material in any developing learning models were considered suitable to be applied. 


\section{Bibliography}

[1]. Anita Lie. 2000. Cooperative Learning Mempraktikkan Cooperative Learning DiRuang-Ruang Kelas. Jakarta : Grasindo.

[2]. Ibrahim, R dan Syoadih, Nana. 1996. Perencanaan Pengajaran. Jakarta : Rineka. Cipta.

[3]. Ibrahim, Muslimin dkk. 2000. Pembelajaran Kooperatif. Surabaya : UNESA.

[4]. Muhsin, Arief. M. 2012. Pembelajaran Media Songs Base Learning Siswa Kelas Vii Smp Negeri 1 Sinjai Borong Kabupaten Sinjai. MEDIA, 1(2), 223-241.

[5]. Muhsin, Arief.M. 2016. The Effectiveness of Positive Feedback in Teaching Speaking Skill. Lingua Cultura, 10(1), 25-30.

[6]. Mulawakkan.2012. Efektivitas Pembelajaran Matematika melalui Pendekatan Problem PosingSetting Kooperatif pada Siswa Kelas IX SMP Negeri 21 Makassar.Skripsi.Tidak diterbitkan. Makassar, FKIP : Unismuh Maassar

[7]. Nasution, S. 1986. Didaktik Asas-asas Mengajar.Bandung :Jemmars.

[8]. Nurjannah. 2004. Upaya Meningkatkan Hasil Belajar Matematika Melalui Model Pembelajaran Koperatif dengan Pendekatan struktural Siswa Kelas I SLTP Negeri 2 Sibulue Kabupaten Bone. Skripsi.Tidak diterbitkan. Makassar, FMIPA : Universitas Negeri Makassar.

[9]. Pasaribu, L.L dan Simandjuntak, B. 1983.Proses Belajar Mengajar.Bandung : Tarsito.

[10]. Paddupai, Darwing dan Mulbar, Djalaluddin.1999. Strategi Pembelajaran Kooperatif Dalam Pengajaran Matematika di Sekolah Dasar.Ujungpandang : Jurusan pendidikan Matematika FMIPA IKIP Ujungpandang.

[11]. Roestiyah, N.K. 1994. Didaktik Metodik. Jakarta : Bumi Aksara.

[12]. Slameto. 2003. Belajar dan Faktor-faktor yang Mempengaruhinya. Jakarta : Rineka Cipta.

[13]. Suherman, Erman Dkk. 2003.Strategi Pembelajaran Matematika Kontemporer. Bandung : Jurusan Pendidikan Matematika FMIPA Universitas Pendidikan Indonesia.

[14]. Sudjana, Nana.1999. Penilaian Hasil Proses Belajar Mengajar.Bandung : Remaja Rosdakarya.

[15]. Usman Uzer. Moh. 1995. Menjadi Guru Profesional. Bandung : Remaja Rosdakarya. 